University of Michigan Law School

University of Michigan Law School Scholarship Repository

Articles

Faculty Scholarship

1907

\title{
The American Bar Association's Meeting at Portland
}

Henry M. Bates

University of Michigan Law School

Available at: https://repository.law.umich.edu/articles/1227

Follow this and additional works at: https://repository.law.umich.edu/articles

Part of the Constitutional Law Commons

\section{Recommended Citation}

Bates, Henry M. "The American Bar Association's Meeting at Portland." Mich. L. Rev. 6 (1907): 53-7.

This Response or Comment is brought to you for free and open access by the Faculty Scholarship at University of Michigan Law School Scholarship Repository. It has been accepted for inclusion in Articles by an authorized administrator of University of Michigan Law School Scholarship Repository. For more information, please contact mlaw.repository@umich.edu. 


\section{MICHIGAN LAW REVIEW}

PUBLISHED YONTHLY DURING THE ACADEXIC YEAR, EXCIUSIVE OF OCTOEEX, BY THE LAW FACULTY OF THE UNIVERSITY OF MICHIGAN

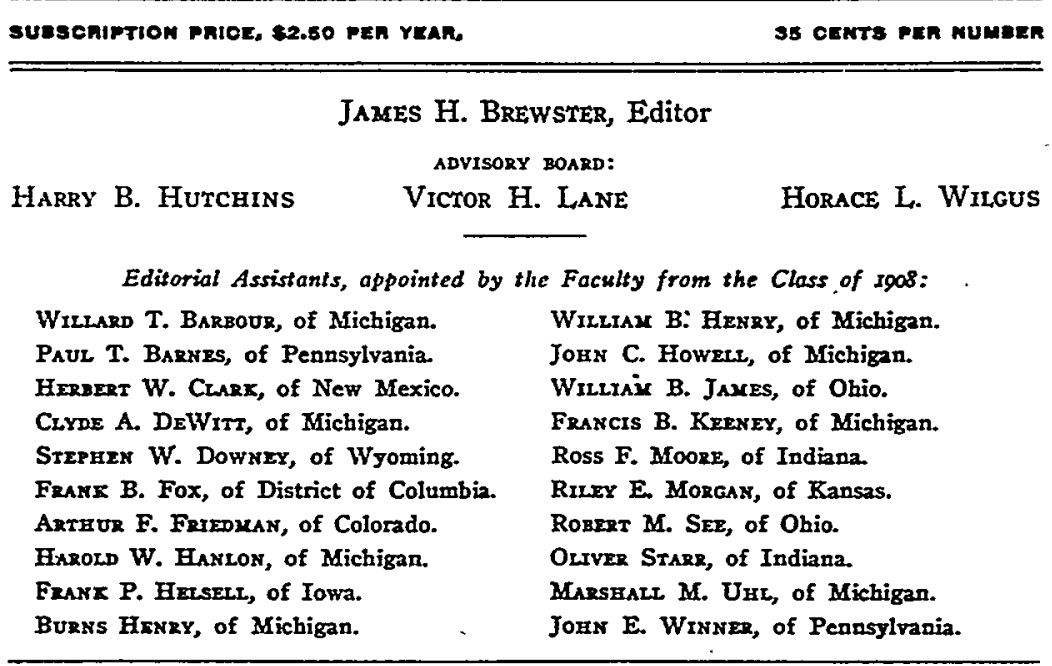

\section{NOTE AND COMMENT}

The American Bar Association's Mefering at Portland.-The meeting of the American Bar Association for 1907 was a notable one, both in respect of the attendance and in the importance of many of the matters discussed. Not only was the attendance unusually large, but the presence of many distinguished men from abroad who were delegates to the meetings of the International Law Association, held during the same week, added distinction to the gatherings. The meetings reflected significantly the discussion throughout the country upon the great legal and political questions which the changing conditions in the commercial and industrial world have brought so prominently before the nation during the last few years. Three of the principal addresses were concerned directly with the divergent views regarding the proper construction of the Constitution of the United States particularly as bearing upon the control of commerce.

Judge Alton B. Parker, in his address to the Association as its President, presented with great ability, earnestness and dignity the views of constitutional construction entertained by those who favor the somewhat strict interpretation of our Federal organic law, and who fear that we have already 
stretched that instrument to the cracking point in the direction of centralization. Referring evidently to recent propositions looking to the Congressional regulation of the relations between employer and employee engaged in inter-state commerce, Judge PARKER said: "Another contention of far reaching import is that the power of Congress to regulate commerce which has been held to include the right to regulate the instrumentalities through which inter-state commerce is conducted, involves the power to regulate the producer of articles of commerce which may or may not be designed to enter later into inter-state commerce. It is insisted that any attempted regulation may be made effective by prohibiting the goods of the manufacturer, or the crops of the farmer, from the channels of inter-state commerce." This contention, Judge PARKER says in effect, violates the Federal Constitution and directly leads to the destruction of our dual government. And in this connection Judge PARKER quotes the well-known words from. Washington's farewell address: "If in the opinion of the people the distribution or modification of the constitutional powers be in any particular wrong, let it be corrected by amendments in the way which the Constitution designates. But let there be no change by usurpation; for though this in one instance may be the instrument of good, it is the customary way in which free governments are destroyed. The precedent must always overbalance in permanent evil any partial or transient benefit which the use can at any time yield." Judge PARKER also declares that the tenth amendment to the Constitution, as well as the construction heretofore given to it, leave "no room for finding in the language of the Constitution a claim that there are certain unmentioned and inherent powers which the Federal Government may exercise." On the authority of Kidd v, Pearson, 128 U. S. I, the speaker said: "An attempt therefore to deny to the harmless and useful products of a state entry into inter-state commerce, would violate the letter and spirit of the Constitution." Evidently this was said with the "Beveridge Child Labor Law" in mind.

Any further extension of federal control in the directions indicated would be "to despoil the states of powers and. functions belonging to them." The address closed with a scathing denunciation of the great increase in careless, useless, and even vicious legislation, which has been so marked during the last few years.

A paper entitled "The Nation and the Constitution," by Judge Charles F. AmIDoN of the United States District Court for North Dakota, though of course not so designed, seemed a direct answer to Judge PArker. The central thought in Judge Axroos's paper may be indicated by the following quotations: "With a practical, rapidly progressive people like ours, the Pharisaical doctrine that the nation exists for the Constitution instead of the Constitution for the nation, can never attain perfect acceptance. That instrument performs its chief service when it holds the nation back from hasty and passionate action, so that government shall not embody the passion of the hour but the settled principles of years. The Constitution cannot be amended in the manner which it provides for that purpose. Since I804 more than 2,000 
amendments have been proposed. Many of them have been the subject of much public discussion, but with the exception of the war amendments all have failed of adoption. * * * Furthermore, amendment is not suitable to bring about those slight but steady modifications of fundamental law which are adapted to the progressive life of the nation. It is far too violent a remedy for that purpose. The method by which the Constitution has been amended during our century of experience has the entire approval of the nation, and must now be accepted as a part of our frame of government, of equal validity with the Constitution itself."

Judge Amroon believes that the transportation agencies need efficient and extensive federal control and that state regulation will not suffice. On this point he said: "Hitherto state regulation has been inefficient, and for that reason alone its localizing power has not become manifest. It is now becoming organized, energetic and effective. If continued it will work its inevitable result. No rivalry can surpass that of our commercial centers, and state governments, let their authority be efficient, will represent their own commercial interests. The national government and the states cannot prescribe rules to the same instrumentality without being brought into constant conflict."

Nowhere perhaps has better expression been given to the views of the modern schools of strict and liberal construction of the Constitution than in these two papers. If it may be said that Judge PARKER's paper presents the theory more consistent with the early constitutional decisions of the Supreme Court, it must also be said that it fails to take account of, or at least to provide for, the radical changes in our national, commercial, industrial and transportation systems of the last few years, changes which demand recognition and regulation in law. It is true that Judge PARkER concedes. though apparently he does not himself believe it, that greater federal control of commerce and transportation may have become necessary, but this he insists must be provided for, if at all, by an amendment to the Constitution. The almost insuperable difficulties in effecting such an amendment are clearly pointed out by Judge Axinow, and there is no proof that the greater mobility of our people in recent years and the increase in the dispersion of intelligence, have in any great measure removed these difficulties.

A paper written by Honorable C. A. Proury of the Inter-State Commerce Commission, after declaring that "the most important social question before this country today is the regulation of its railways," makes an earnest plea for the reorganization of the commission of which he is a nember, or the organization of an auxiliary body, in order that the two inconsistent functions of investigating transportation conditions, and of judicial action affecting railways, at present lodged in the one body, the Inter-State Commerce Commission, may be separated and exercised by bodies constituted with reference to their ability to perform such functions. Judge Prouty did not undertake to point out in any definite way how this might be accomplished, and it would seem that there are legal difficulties in the way of the accomplishment of the reorganization which he proposes, difficulties which may prove insurmountable. 
As has been the case during all of the recent meetings of the Association, the report of the Insurance Committee was the occasion of discussion so animated as to border at times upon acrimony. The feature of the report of this year's committee which produced most opposition, was the recommendation that the privileges of the United States mail be denied to so-called "wild cat" insurance companies, which refuse 10 incorporate in accordance with the law. It may be that the bill proposed by the committee was somewhat too sweeping in its terms, but the end aimed at is one to be desired by all, and it would seem that the objections to the method proposed might be cured by slight modifications of the draft presented. To one not especially interested in the matter the solicitude felt by some gentlemen lest this innocent bill should bring about the destruction of constitutional government seemed rather ludicrous.

The report of the Committee on Patent Law, recommending the adoption of its revised bill for the establishment of a special court of last resort for patent law controversies was adopted with but little, opposition. Again the objection was raised that the designation by the Supreme Court of those federal judges who should comprise the proposed new court would violate the constitutional requirement that all federal judges shall be nominated and appointed by the President, etc. As, however, the judges thus designated have already been appointed by the President, the objection seems untenable, and was evidently so regarded by the Bar Association.

An important report by the Committee on Copyright Law was also adopted in toto. Among the recommendations were, (I) a broadening of the subject of copyright to include all classes of works which can be included within the constitutional term "writings of an author;" (2) the recognition of a right of property in all the works of an author, before as well as after publication, provided a notice of claim of copyright is impressed upon or attached to the work at the time of publication; (3) the enlarging of the rights of aliens to the extent that any person resident in any part of the world may obtain American copyright under certain conditions.

Of especial interest to law teachers and scholars were the proceedings of the Section on Legal Education, and of the Association of American Law Schools. A Bureau of Comparative Law was established under resolutions of the Bar Association, and aid was pledged to this bureau by the law school association. This bureau is to undertake the publication of an annual bulletin of legislative titles and general bibliography of foreign laws covering the preceding year, and to encourage, supervise and edit translations of such fundamental foreign laws and modern enactments as may be desirable and financially possible. This is a work which the legal scholarship of the country has long been in need of. Under the able leadership of Dean Kirchwey much may be expected. Chairman Pound of the Legal Education Section presented a suggestive paper on the need of a sociological jurisprudence. 
President W. P. Rogers of the Association of American Law Schools in his presidential address made an earnest plea for an increase in entrance requirements in all law schools and urged the adoption of the requirement of a course of two years' preliminary study in a standard college or university by all candidates for a degree of LL.B.

The most striking paper read before the law school association was one by Professor A. M. Kales, of Northwestern University, in which he maintained that the case books now generally in use have become seriously defective in not going far enough in equipping students for actual practice at the bar in the older jurisdictions, such as New York, Pennsylvania and Massachusetts, in that the present case book seeks to set forth the ideal law, drawn from those cases in England and in various states, which, in the opinion of the editor are most nearly what the law should be; and that therefore they do not teach the law as it exists in those jurisdictions having a settled jurisprudence of their own. It was pointed out in answer to Professor Kales's paper, that the aim of a law school should be training quite as much as the imparting of information, and that a thorough study of the best obtainable body of law was the best preparation for the practice of law in any state, and furthermore that the adoption of state case books would tend most unfortunately to such a divergence in the growth of law in the different jurisdictions as to make the already chaotic conditions unendurable.

H. M. B. 